Case Report

\title{
Agenesis of Submandibular Glands: A Report of Two Cases with Review of Literature
}

\author{
Medine Kara, ${ }^{1}$ Oğuz Güiçlü, ${ }^{1}$ Fevzi Sefa Dereköy, ${ }^{1}$ Mustafa Resorlu, ${ }^{2}$ and Gürhan Adam ${ }^{2}$ \\ ${ }^{1}$ Department of Otolaryngology, Canakkale Onsekiz Mart University Medical Hospital, Canakkale, Turkey \\ ${ }^{2}$ Department of Radiology, Canakkale Onsekiz Mart University Medical Hospital, Canakkale, Turkey
}

Correspondence should be addressed to Medine Kara; medinekara@gmail.com

Received 20 May 2014; Revised 16 August 2014; Accepted 22 August 2014; Published 1 September 2014

Academic Editor: Kenichi Takano

Copyright (C) 2014 Medine Kara et al. This is an open access article distributed under the Creative Commons Attribution License, which permits unrestricted use, distribution, and reproduction in any medium, provided the original work is properly cited.

Background. Congenital absence of the submandibular gland (SMG) is a rare condition. Although complaints such as dry mouth, dental problems, or difficulty in swallowing may be seen, the subjects may also be asymptomatic. The absence of the SMG may be associated with hypertrophy of the contralateral SMG. Case Report. We report the case of a 44-year-old woman with incidentally detected left SMG aplasia, with contralateral SMG hypertrophy mimicking a mass, and the case of a 46-year-old woman with incidentally detected bilateral SMG aplasia, demonstrated by computerized tomography (CT) and magnetic resonance imaging (MRI). Conclusion. It is important for the clinician to know that this very rare abnormality may exist. When such a case is encountered, symptoms and findings should be reevaluated and, if necessary, conservative therapy should be initiated. The possibility of observing additional deformities should be kept in mind and an evaluation should be done for other cases in the family.

\section{Introduction}

Congenital absence of the submandibular gland (SMG) is a rare condition. The term "aplasia" is described as the total or partial agenesis of the gland [1]. In the English medical literature, approximately 40 cases have been reported to date. The first case was presented in 1885 by Gruber and was a bilateral SMG aplasia [2]. Although its etiology is not known, it is thought to result from a defect that occurs during fetal development. In such subjects, additional developmental deformities may also be observed. Clinical syndromes, such as lacrimo-auriculo-dento-digital syndrome and mandibulofacial-dysostosis (Treacher-Collins syndrome), may also be seen [3]. Unilateral SMG aplasia is often asymptomatic and is usually discovered incidentally through imaging [4].

Due to an inadequate amount of saliva in these cases, some symptoms such as dry mouth, dental problems, and difficulty swallowing are seen. However, while asymptomatic subjects constitute approximately half of the cases, there are also subjects that are arbitrarily diagnosed.

In this study, two cases-a patient with bilateral submandibular aplasia and a patient with unilateral submandibular aplasia-are reported and discussed based on the literature.

\section{First Case}

A 46-year-old female patient was presented to our clinic with a palpable mass. In the physical examination, her thyroid gland was palpated as bilateral hypertrophic. In the palpation, nodular formations were detected in both lobes. The thyroid hormone levels were within normal limits. In the ultrasound (US) examination, the right lobe of the thyroid was measured at $13 \times 4 \times 4 \mathrm{~cm}$ and the left lobe was measured at $9 \times 3 \times 3 \mathrm{~cm}$. Additionally, the isoechoic nodular structures were observed, the largest of which was on the right with a diameter of $32 \mathrm{~mm}$ while the left had a diameter of $26 \times 19 \mathrm{~mm}$ with retrosternal extension. In the nodular structures, peripheral and intranodular bleeding was observed. A fine-needle aspiration biopsy was performed and the result showed a benign cytology. To determine its relation with the surrounding tissue, a computerized tomography (CT) of the neck was requested. In the CT scan, it was observed that the thyroid gland extended into the submandibular area and the SMG was bilaterally absent (Figures 1 and 2). Thereafter, the patient was asked if she had a dry mouth, difficulty swallowing, or dental problems, which may occur due to the absence of salivary glands. The oral cavity was reevaluated and the 


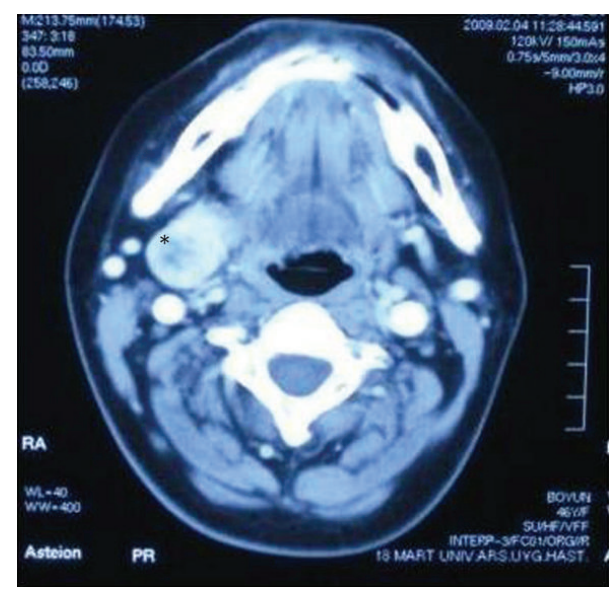

FIGURE 1: Thyroid mass extension to submandibular area in the first case. "*” The thyroid mass.

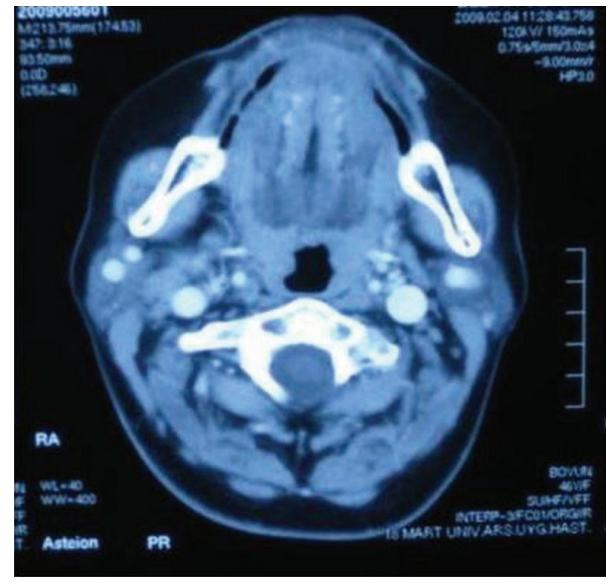

FIgURE 2: Bilateral absence of submandibular gland in the first case.

presence of Wharton channel and orifice was examined. A search was done for the presence of an additional deformity, but no additional pathology was detected. The family of the patient did not have any history of this clinical presentation.

\section{Second Case}

A 44-year-old female patient complaining of neck pain with a cervical magnetic resonance imaging (MRI) agenesis of the left SMG was consulted in our clinic. On physical examination, no palpable mass was detected in the head and neck region. She had no specific relevant medical history such as dry mouth, dysphagia, teeth and gum problems, or sialadenitis. Agenesis of the left SMG and compensatory hypertrophy in the right SMG were observed in the CT and MRI scans (Figures 3 and 4).

\section{Discussion}

In the literature (Table 1), there is no information about the incidence of the congenital absence of the major SMG;

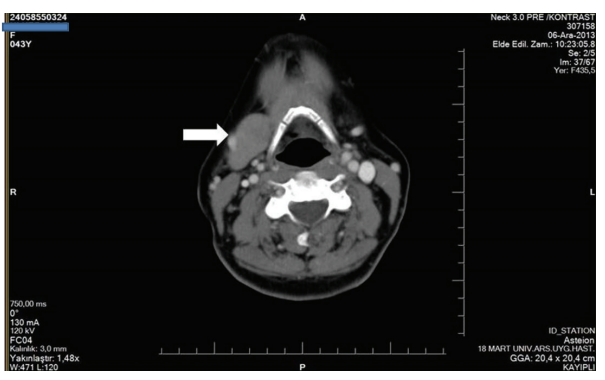

FIgURE 3: Noncontrast computed tomography axial sections demonstrate absence of left submandibular gland in the second case. White arrow shows the right submandibular gland.

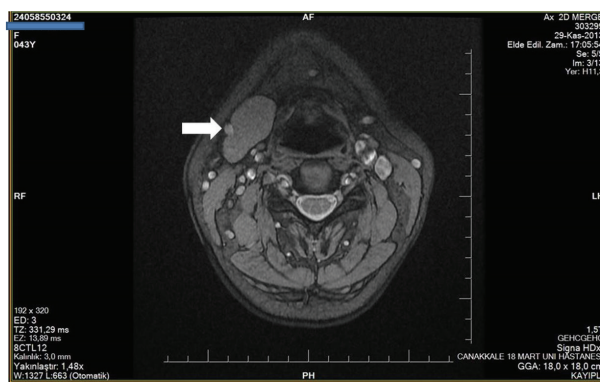

FIgURE 4: Magnetic resonance image axial sections demonstrate absence of left submandibular gland in the second case. White arrow shows the right submandibular gland.

however, to date, approximately 40 cases have been reported [2]. Salivary glands may show unilateral or bilateral aplasia and aplasia of one or more groups. Total or partial agenesis may be observed [3]. Although the etiology of congenital absence of the SMG is unknown, it is thought to result from a defect occurring during fetal development [5]. Submandibular aplasia may also accompany deformities related to the first and second branchial arch abnormalities. Genetic syndromes may also be seen, such as Treacher-Collins syndrome, hemifacial microsomia, ectodermal dysplasia, and lacrimoauriculo-dento-digital syndrome. In these cases, autosomal dominant inheritance is thought to exist. In the examinations performed in our cases, no additional deformity was detected; however, in cases with more than one salivary gland involved, it is important to screen for other deformities and give genetic counseling if necessary. Furthermore, in cases with developmental deformity, salivary gland abnormalities may also be investigated.

In aplastic cases, dry mouth, difficulty swallowing, and dental problems may be observed. However, approximately half of the cases are asymptomatic [4]. In the literature, there are also some cases that show a compensatory hypertrophy in other glands $[5,6]$. In our second case, there was a compensatory hypertrophy in the right SMG. The decreased amount of saliva may also cause impaired oral hygiene and increase the incidence of opportunistic infections. It causes angular cheilitis near the lips, a decreased sense of taste, and gingival problems. In cases with these kinds of symptoms, although the incidence is low, salivary gland aplasia should be considered in a differential diagnosis. Both of our cases 
TABLE 1: A literature review of the case reports with absence of the submandibular gland.

\begin{tabular}{|c|c|c|c|c|}
\hline Literature & Patient & Presenting symptoms & $\begin{array}{l}\text { The way of } \\
\text { diagnoses }\end{array}$ & Findings \\
\hline $\begin{array}{l}\text { Park et al. [1] } \\
2013\end{array}$ & $\begin{array}{l}\text { A } 56 \text {-year-old } \\
\text { woman }\end{array}$ & $\begin{array}{l}\text { A palpable mass in the left } \\
\text { submandibular area }\end{array}$ & MRI and US & $\begin{array}{l}\text { The right SMG was absent and } \\
\text { replaced with fatty tissue }\end{array}$ \\
\hline $\begin{array}{l}\text { Yilmaz et al. [2] } \\
2002\end{array}$ & $\begin{array}{l}\text { A } 32 \text {-year-old } \\
\text { woman }\end{array}$ & $\begin{array}{l}\text { Pain and tenderness in the left } \\
\text { submandibular region and the } \\
\text { angle of the mandible }\end{array}$ & $\begin{array}{l}\text { CT, US, and } \\
\text { sialography }\end{array}$ & $\begin{array}{l}\text { Absence of the right SMG and } \\
\text { a slightly enlarged left SMG }\end{array}$ \\
\hline Roh [4] 2006 & $\begin{array}{l}\text { A } 67 \text {-year-old } \\
\text { man }\end{array}$ & Hoarseness for 10 months & $\begin{array}{l}\text { CT scan of the } \\
\text { neck }\end{array}$ & Absence of the right SMG \\
\hline $\begin{array}{l}\text { Mathison and } \\
\text { Hudgins [5] } \\
2008\end{array}$ & $\begin{array}{l}\text { A } 34 \text {-year-old } \\
\text { female }\end{array}$ & $\begin{array}{l}\text { Stage IIIA nodular sclerosing } \\
\text { Hodgkin lymphoma, in the } \\
\text { routine control examination }\end{array}$ & $\begin{array}{l}\text { A CT scan of the } \\
\text { neck with contrast }\end{array}$ & $\begin{array}{l}\text { Aplasia of bilateral SMGs and } \\
\text { moderate enlargement of } \\
\text { bilateral SLG }\end{array}$ \\
\hline $\begin{array}{l}\text { Srinivasan et al. } \\
\text { [6] } 2006\end{array}$ & $\begin{array}{l}\text { A } 35 \text {-year-old } \\
\text { woman }\end{array}$ & Facial pressure and rhinorrhea & $\begin{array}{l}\text { CT scan of the } \\
\text { paranasal sinuses }\end{array}$ & $\begin{array}{l}\text { Absence of the right SMG, } \\
\text { with a "mass" in the right } \\
\text { sublingual space in the } \\
\text { expected location of the right } \\
\text { SLG }\end{array}$ \\
\hline $\begin{array}{l}\text { Kubo et al. [9] } \\
1990\end{array}$ & $\begin{array}{l}\text { A 34-year-old } \\
\text { male }\end{array}$ & $\begin{array}{l}\text { Pain radiating from his right } \\
\text { mandibular body to the temporal } \\
\text { region }\end{array}$ & $\begin{array}{l}\text { CT was } \\
\text { undertaken to } \\
\text { examine his } \\
\text { cerebral status }\end{array}$ & Absence of the right SMG \\
\hline $\begin{array}{l}\text { Fracaro et al. } \\
{[10] 2002}\end{array}$ & $\begin{array}{l}\text { A 13-year-old } \\
\text { female }\end{array}$ & $\begin{array}{l}\text { Severe progressive dental caries } \\
\text { and enamel demineralization of } \\
\text { the permanent mandibular } \\
\text { incisor teeth }\end{array}$ & $\begin{array}{l}\text { Scintigraphy with } \\
\text { technetium-99m } \\
\text { pertechnetate }\end{array}$ & Absence of bilateral SMGs \\
\hline \multirow{3}{*}{$\begin{array}{l}\text { Gallego et al. } \\
{[11] 2009} \\
\text { Kooet al. }[12] \\
2009\end{array}$} & $\begin{array}{l}\text { A } 35 \text {-year-old } \\
\text { woman }\end{array}$ & $\begin{array}{l}\text { Dry lips and mouth, difficulty } \\
\text { with swallowing solid foods, } \\
\text { changes in taste, and occasional } \\
\text { angular cheilitis over the } \\
\text { previous four years }\end{array}$ & $\mathrm{CT}$ & $\begin{array}{l}\text { Complete aplasia of the right } \\
\text { SMG with compensatory } \\
\text { hypertrophy of other mayor } \\
\text { salivary glands }\end{array}$ \\
\hline & $\begin{array}{l}\text { A } 48 \text {-year-old } \\
\text { woman and }\end{array}$ & Cervical lymphadenopathy. & $\mathrm{CT}$ & $\begin{array}{l}\text { The left SMG was absent and } \\
\text { the area was replaced by fat }\end{array}$ \\
\hline & $\begin{array}{l}\text { a } 42 \text {-year-old } \\
\text { woman }\end{array}$ & $\begin{array}{l}\text { Palpable mass in the floor of the } \\
\text { mouth }\end{array}$ & $\mathrm{CT}$ & $\begin{array}{l}\text { The right SMG was absent and } \\
\text { the area was replaced by fat }\end{array}$ \\
\hline $\begin{array}{l}\text { Gupta et al. [13] } \\
2009\end{array}$ & $\begin{array}{l}\text { A } 35 \text {-year-old } \\
\text { woman and } \\
\text { a } 7 \text {-year-old boy }\end{array}$ & $\begin{array}{l}\text { Prominent posterior cervical } \\
\text { lymphadenopathy } \\
\text { Symptoms consistent with viral } \\
\text { illness }\end{array}$ & CT and MRI & $\begin{array}{l}\text { Both patients were noted to } \\
\text { have unilateral aplasia of the } \\
\text { right SMG and hypertrophy of } \\
\text { the opposite gland }\end{array}$ \\
\hline $\begin{array}{l}\text { Damar et al. [14] } \\
2013\end{array}$ & $\begin{array}{l}\text { A } 55 \text {-year-old } \\
\text { female }\end{array}$ & $\begin{array}{l}\text { Myogenic pain radiating from } \\
\text { the left shoulder to the left neck } \\
\text { and hoarseness }\end{array}$ & US & $\begin{array}{l}\text { Unilateral aplasia of the left } \\
\text { SMG }\end{array}$ \\
\hline Yerli [15] 2014 & $\begin{array}{l}\text { A } 19 \text {-year-old } \\
\text { woman }\end{array}$ & $\begin{array}{l}\text { A mass in left submandibular } \\
\text { area }\end{array}$ & US & $\begin{array}{l}\text { Aplasia of the left SMG and } \\
\text { compensatory hypertrophy of } \\
\text { the left SLG }\end{array}$ \\
\hline $\begin{array}{l}\text { Aiyappan et al. } \\
\text { [16] } 2010\end{array}$ & $\begin{array}{l}\text { A } 60 \text {-year-old } \\
\text { woman }\end{array}$ & $\begin{array}{l}\text { Symptoms of sudden-onset } \\
\text { left-sided hemiplegia }\end{array}$ & $\begin{array}{l}\text { Nonenhanced CT } \\
\text { examination }\end{array}$ & $\begin{array}{l}\text { Absence of the left SMG and } \\
\text { few small lymph nodes were } \\
\text { seen in the left submandibular } \\
\text { triangle }\end{array}$ \\
\hline $\begin{array}{l}\text { Haktanir [17] } \\
2012\end{array}$ & $\begin{array}{l}\text { A 13-year-old } \\
\text { girl }\end{array}$ & $\begin{array}{l}\text { Bilateral submandibular masses } \\
\text { pronounced with swallowing }\end{array}$ & US and CT & $\begin{array}{l}\text { Bilateral absence of SMG and } \\
\text { compensatory hypertrophy of } \\
\text { the bilateral SLG }\end{array}$ \\
\hline $\begin{array}{l}\text { Ahmed et al. } \\
\text { [18] } 2009\end{array}$ & $\begin{array}{l}\text { A } 62 \text {-year-old } \\
\text { male }\end{array}$ & Left submandibular mass & $\mathrm{CT}$ & $\begin{array}{l}\text { Bilateral absence of SMG and } \\
\text { bilateral hypertrophied } \\
\text { sublingual salivary tissue }\end{array}$ \\
\hline
\end{tabular}


TABle 1: Continued.

\begin{tabular}{lllll}
\hline Literature & Patient & Presenting symptoms & $\begin{array}{l}\text { The way of } \\
\text { diagnoses }\end{array}$ & Findings \\
\hline $\begin{array}{l}\text { Reija et al. [19] } \\
2013\end{array}$ & $\begin{array}{l}\text { A 41-year-old } \\
\text { woman }\end{array}$ & $\begin{array}{l}\text { Intermittent bilateral } \\
\text { submandibular swelling and } \\
\text { xerostomia }\end{array}$ & US and MRI & $\begin{array}{l}\text { Bilateral and symmetrical } \\
\text { hypertrophy of both } \\
\text { SLGs with bilateral absence of } \\
\text { the SMGs }\end{array}$ \\
$\begin{array}{l}\text { Shipchandler } \\
\text { and Lorenz [20] }\end{array}$ & $\begin{array}{l}\text { A 60-year-old } \\
\text { male }\end{array}$ & $\begin{array}{l}\text { After resection of tumor of } \\
\text { tongue fullness in the right } \\
\text { submandibular region }\end{array}$ & CT & $\begin{array}{l}\text { Aplasia of the left SMG with } \\
\text { contralateral gland } \\
\text { hypertrophy }\end{array}$ \\
\hline $\begin{array}{l}\text { Yilmaz et al. [21] } \\
2010\end{array}$ & $\begin{array}{l}\text { A 41-year-old } \\
\text { woman }\end{array}$ & $\begin{array}{l}\text { Dry lips and mouth, difficulty } \\
\text { with swallowing solid foods, } \\
\text { heartburn, and changes in taste, } \\
\text { over the previous 5 years }\end{array}$ & US, CT, and MRI & $\begin{array}{l}\text { Absence of the right } \\
\text { submandibular } \\
\text { gland with compensatory } \\
\text { hypertrophy of the ipsilateral } \\
\text { SLG }\end{array}$ \\
\hline
\end{tabular}

CT: computerized tomography, MRI: magnetic resonance imaging, SMG: submandibular gland, SLG: sublingual gland, and US: ultrasound.

were detected incidentally. After determining the existing condition of our patients, they did not describe any additional problems in subsequent questioning. In this regard, we think that the absence of symptoms was caused by an adequate flow of saliva ensured by other glands.

Although, bimanual palpation is absolutely necessary in the diagnosis of SMG aplasia, it does not provide adequate information. Evaluating the presence of the Wharton channel and its orifice is necessary. In total agenesis, the orifice and channel may not be observed. In fact, the diagnosis is determined radiologically. The methods that may be preferred in this area include US, CT, scintigraphy, MRI, and sialography [4]. As some confusion may be occasionally experienced in unilateral aplastic cases or in cases with a compensatory hyperplasia in other glands, having an experienced radiologist is very important. In our first case, a CT was requested for a stage three goiter, which incidentally revealed bilateral SMG aplasia. In the CT scan, it was observed that the thyroid gland extended into the submandibular area. When only these sections were examined, the SMG was clearly observed.

A differential diagnosis of the mass in the submandibular area includes nonmalignant or malignant growths. Nonmalignant swelling may occur as sialadenitis, Sjögren syndrome, cysts, infections, and lymphadenopathy. Neoplastic growths such as the SMG, the tail parotid gland, the Hodgkin's disease, non-Hodgkin's lymphomas, and metastatic disease may be seen [7]. Some rare cases of submandibular swelling have been seen as submandibular localizations of thyroid lesions $[8]$.

In summary, it is important for the clinician to know that this very rare abnormality may exist. When such a case is encountered, symptoms and findings should be reevaluated and, if necessary, conservative therapy should be initiated. The possibility of observing additional deformities should be kept in mind and an evaluation should be done for other cases in the family.

\section{Informed Consent}

Written informed consent was obtained from patients.

\section{Conflict of Interests}

The authors declare that there is no conflict of interests regarding the publication of this paper.

\section{References}

[1] S. H. Park, Y. M. Sohn, and E. K. Kim, "Agenesis of a submandibular gland with compensatory pseudotumoral hypertrophy of the contralateral gland: sonographic findings," Journal of Clinical Ultrasound, vol. 41, pp. 15-17, 2013.

[2] M. D. Yilmaz, A. Yücel, F. S. Dereköy, and A. Altuntaş, "Unilateral aplasia of the submandibular gland," European Archives of Oto-Rhino-Laryngology, vol. 259, pp. 554-556, 2002.

[3] A. P. S. Ferreira, R. S. Gomez, W. H. Castro, N. S. Calixto, R. A. P. Silva, and M. J. B. Aguiar, "Congenital absence of lacrimal puncta and salivary glands," American Journal of Medical Genetics, vol. 94, pp. 32-34, 2000.

[4] J.-L. Roh, "Unilateral submandibular gland aplasia: an isolated phenomenon of early fetal development," Otolaryngology-Head and Neck Surgery, vol. 135, no. 2, pp. 332-334, 2006.

[5] C. C. Mathison and P. A. Hudgins, "Bilateral submandibular gland aplasia with hypertrophy of sublingual glands," Otolaryngology - Head and Neck Surgery, vol. 138, no. 1, pp. 119120, 2008.

[6] A. Srinivasan, J. S. Moyer, and S. K. Mukherji, "Unilateral submandibular gland aplasia associated with ipsilateral sublingual gland hypertrophy," American Journal of Neuroradiology, vol. 27, no. 10, pp. 2214-2216, 2006.

[7] I. Eleftheriadis, P. Papadimitriou, and H. Tzelepi, "Submandibular swelling and its differential diagnosis," Hell Period Stomat Gnathopathoprosopike Cheir, vol. 5, pp. 59-68, 1990.

[8] R. H. Khonsari, C. Bertolus, P. Corre et al., "Submandibular swelling four years after total thyroidectomy," Revue de Stomatologie, de Chirurgie Maxillo-Faciale et de Chirurgie Orale, vol. 115, pp. 118-120, 2014.

[9] S. Kubo, K. Abe, T. Ureshino, and M. Oka, "Aplasia of the submandibular gland: a case report," Journal of Cranio-MaxilloFacial Surgery, vol. 18, no. 3, pp. 119-121, 1990.

[10] M. S. Fracaro, V. M. Linnett, K. B. Hallett, and N. W. Savage, "Submandibular gland aplasia and progressive dental caries: a case report," Australian Dental Journal, vol. 47, pp. 347-350, 2002. 
[11] L. Gallego, L. Junquera, P. Cuesta, and P. Rosado, "Symptomatic unilateral submandibular gland aplasia," British Journal of Oral and Maxillofacial Surgery, vol. 47, no. 3, 243 pages, 2009.

[12] B. S. Koo, S. W. Lee, Y. M. Lee, J. D. Lee, and Y. W. Koh, "Sialolithiasis in a stump of Wharton's duct of an aplastic unilateral submandibular gland," International Journal of Oral and Maxillofacial Surgery, vol. 38, no. 1, pp. 93-95, 2009.

[13] N. Gupta, E. Palacios, and S. Barry, "Unilateral submandibular gland aplasia: a rare phenomenon," Ear, Nose \& Throat Journal, vol. 88, pp. 818-820, 2009.

[14] M. Damar, C. B. Kalayc1, U. Bekar, and B. Turhan, "Unilateral conjenital aplasia of the submandibular gland," Kulak Burun Boğaz İhtisas Dergisi, vol. 23, pp. 53-56, 2013.

[15] H. Yerli, "Dynamic sonography and CT findings of unilateral submandibular gland agenesis associated with herniatedhypertrophic sublingual gland," Journal of Clinical Ultrasound, vol. 42, pp. 176-179, 2014.

[16] S. K. Aiyappan, U. Ranga, and S. Veeraiyan, "Isolated unilateral aplasia of submandibular gland: a rare anomaly detected incidentally on computerized tomography," Oral Surgery, Oral Medicine, Oral Pathology, Oral Radiology, and Endodontology, vol. 110, no. 2, pp. e54-e56, 2010.

[17] A. Haktanir, "CT and MR findings of bilateral submandibular gland aplasia associated with hypertrophied symmetrical sublingual glands herniated through mylohyoid defects," Dentomaxillofacial Radiology, vol. 41, no. 1, pp. 79-83, 2012.

[18] M. Ahmed, M. Strauss, A. Kassaie, V. Shotelersuk, and R. DeGuzman, "Bilateral submandibular gland aplasia with clinico-radiological mass due to prolapsing sublingual salivary tissuethrough mylohyoid boutonniere: a case report and review," Dentomaxillofacial Radiology, vol. 38, pp. 121-124, 2009.

[19] M. F. Reija, D. P. Gordillo, J.C. Palacio, L. B. Abascal, and B. G. Perea, "Bilateral submandibular gland aplasia with hypertrophy of the sublingual glands of a patient with a cleft lip and palate: case report," Journal of Craniofacial Surgery, vol. 24, pp. e532e533, 2013.

[20] T. Z. Shipchandler and R. R. Lorenz, "Unilateral submandibular gland aplasia masquerading as cancer nodal metastasis," The American Journal of Otolaryngology, vol. 29, pp. 432-434, 2008.

[21] M. Yilmaz, E. Karaman, H. Isildak, O. Enver, and F. Kilic, "Symptomatic unilateral submandibular gland aplasia associated with ipsilateral sublingual gland hypertrophy," Dysphagia, vol. 25 , pp. 70-72, 2010. 


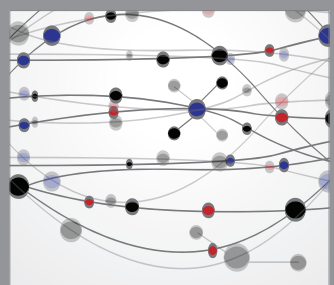

The Scientific World Journal
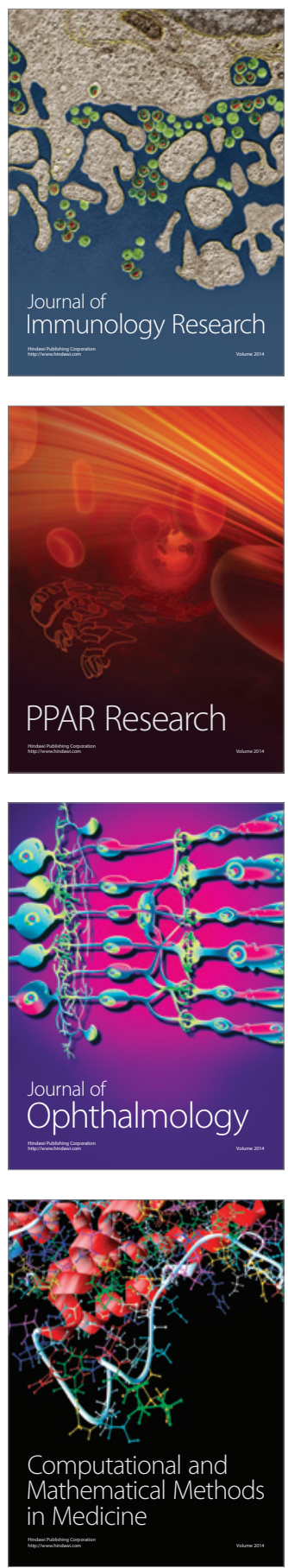

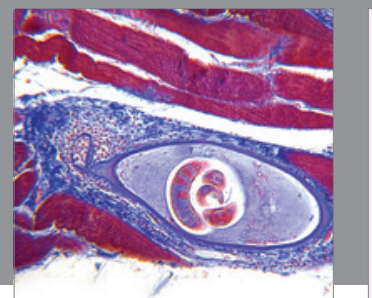

Gastroenterology

Research and Practice
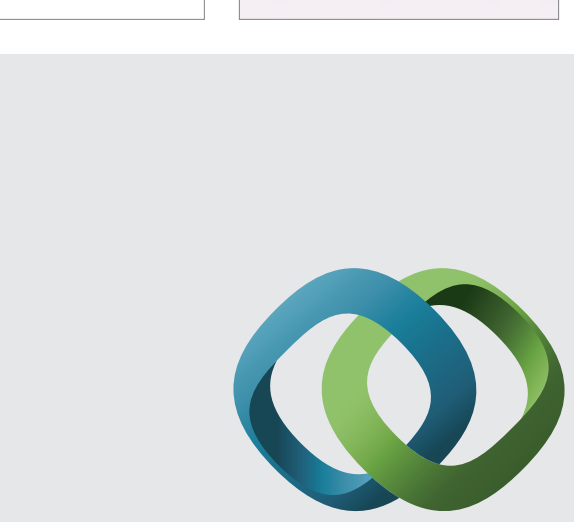

\section{Hindawi}

Submit your manuscripts at

http://www.hindawi.com
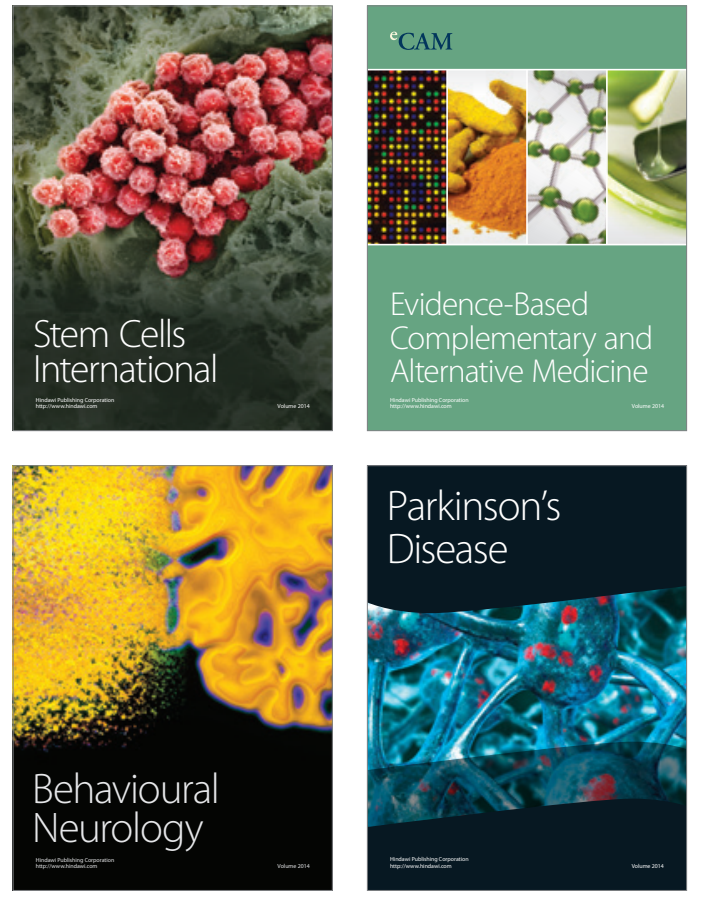
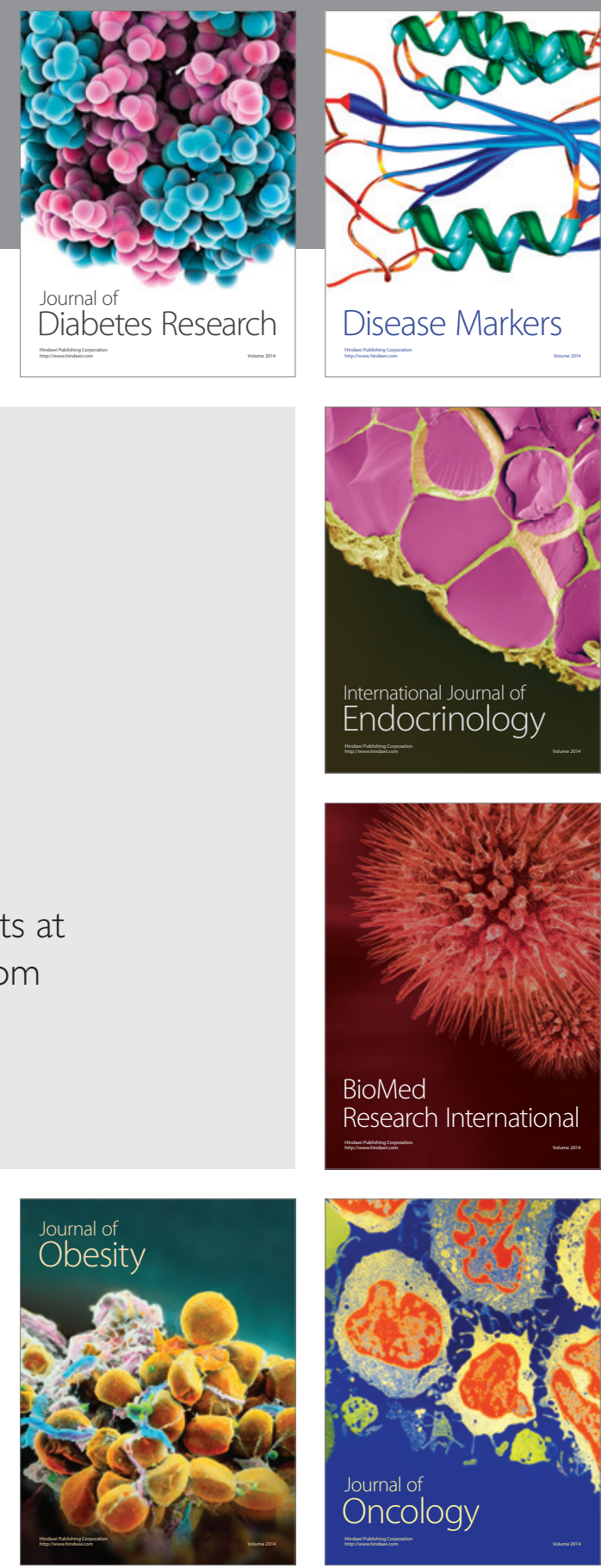

Disease Markers
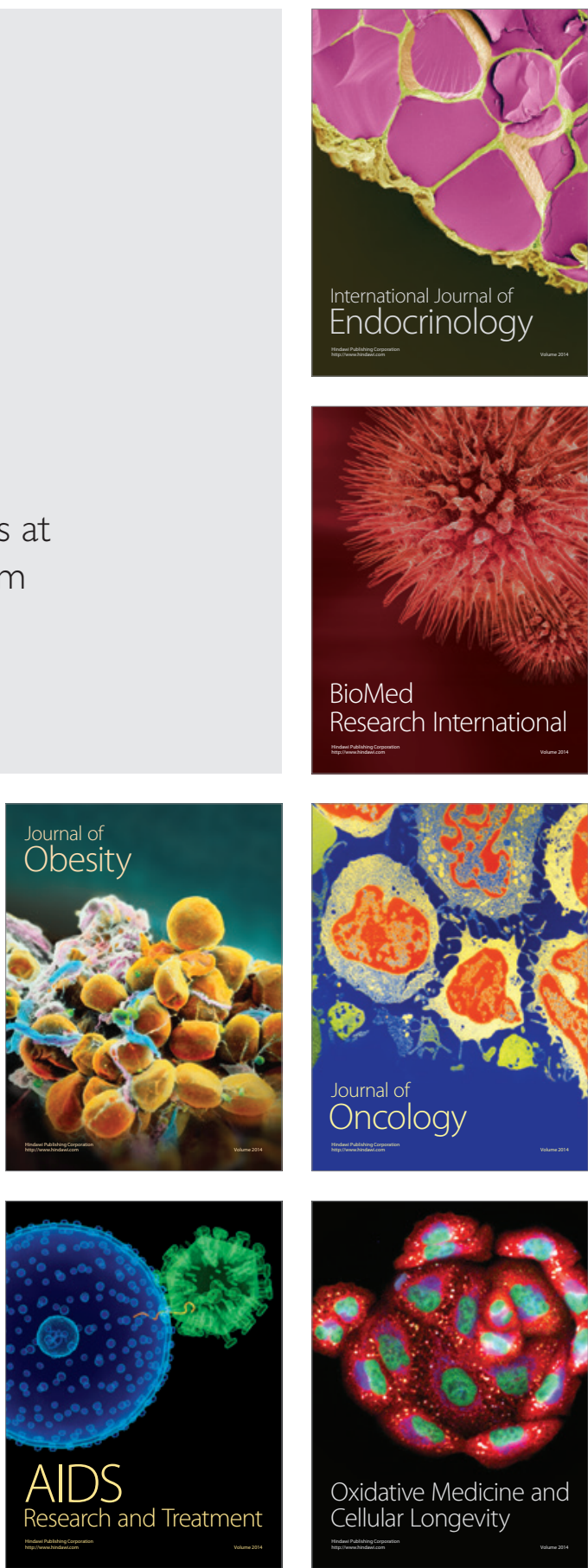